Division of Geological \& Geophysical Surveys

PRELIMINARY INTERPRETIVE REPORT 2013-2

\title{
SUMMARY OF 2012 RECONNAISSANCE FIELD STUDIES RELATED TO THE PETROLEUM GEOLOGY OF THE NENANA BASIN, INTERIOR ALASKA \\ by
}

Marwan A. Wartes, Robert J. Gillis, Trystan M. Herriott, Richard G. Stanley, Kenneth P. Helmold, C. Shaun Peterson, and Jeffrey A. Benowitz

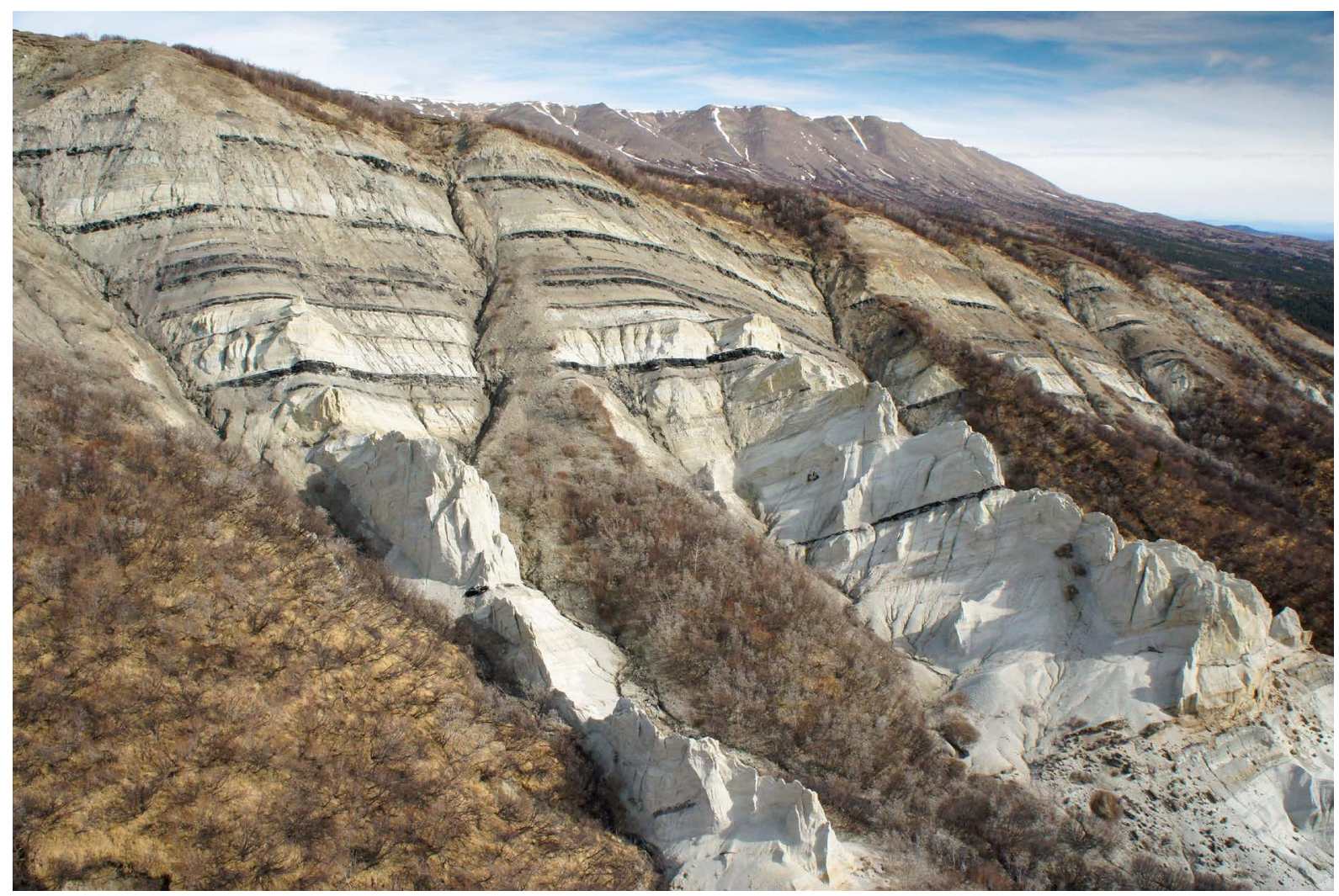

Oblique aerial view northeastward of coal-bearing Usibelli Group strata in the headwaters of Coal Creek, a Wood River tributary, approximately 60 miles south of Fairbanks, Alaska. The middle Miocene Suntrana Formation comprises the package of light gray- to whitish gray-weathering sandstone and subordinate coal, which is overlain by a light gray-brown-weathering, coal-rich section of middle-late Miocene Lignite Creek Formation. A gently northward dipping panel of Pliocene Nenana Gravel lies along the background skyline. Our current work is directed toward better understanding the geologic framework of the Usibelli Group, and thus shed light on the potential oil and gas resources in the Nenana basin west of Fairbanks. See page 9 of this report for further information about the Coal Creek area exposures. Two geologists (for scale) are standing in shadow to the right of photo center. Photograph by Trystan Herriott.

February 2013

Released by

STATE OF ALASKA

DEPARTMENT OF NATURAL RESOURCES

Division of Geological \& Geophysical Surveys

3354 College Rd.

Fairbanks, Alaska 99709-3707 



\section{CONTENTS}

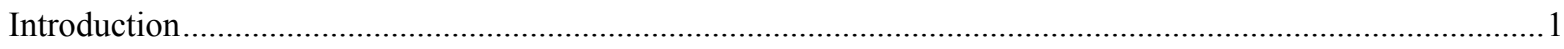

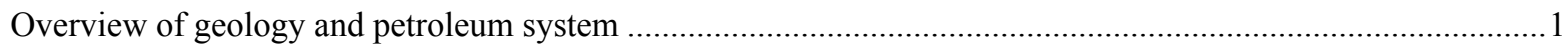

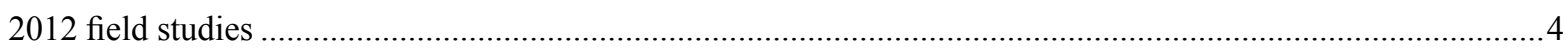

Detailed reservoir quality sampling of Usibelli Group at Suntrana ........................................................5

Source rock sampling of the lacustrine Sanctuary Formation.......................................................................

Detailed measured sections and facies analysis ......................................................................................

Grubstake Formation..........................................................................................................

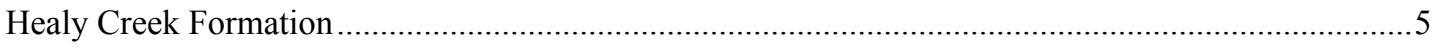

Reconnaissance facies analysis and sampling of the Wood River area.......................................................

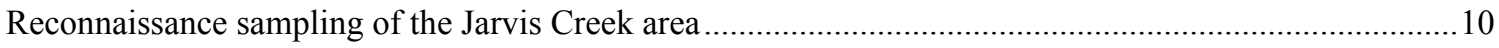

Thermochronologic sampling in the Alaska Range and Yukon-Tanana Upland ......................................... 10

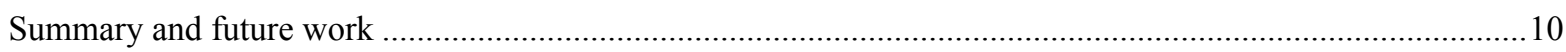

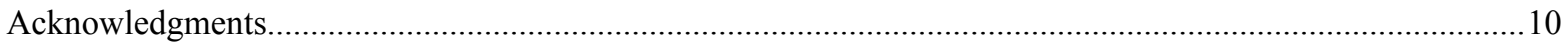

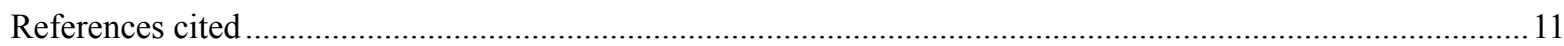

\section{FIGURES}

Figure 1. Location map of interior Alaska, highlighting 2012 field stations and salient geologic

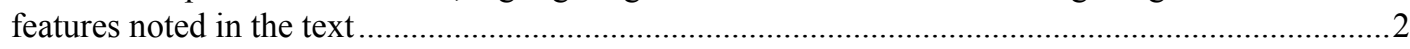

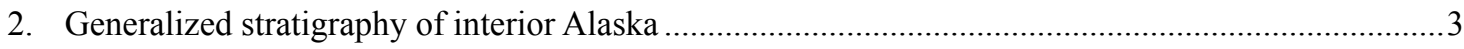

3. Photo of the upper part of the type section of the Usibelli Group at Suntrana ....................................

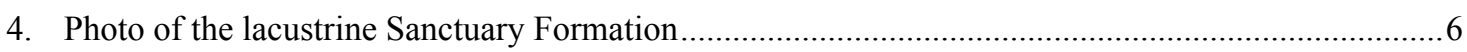

5. Photos from the measured section of the Grubstake Formation along Tatlanika Creek .......................7

6. Photos from the measured section of the Healy Creek Formation near the confluence of

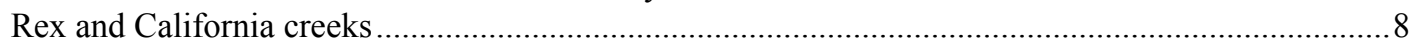

7. Photo of well exposed section along Coal Creek, a tributary to the Wood River..................................9 



\title{
SUMMARY OF 2012 RECONNAISSANCE FIELD STUDIES RELATED TO THE PETROLEUM GEOLOGY OF THE NENANA BASIN, INTERIOR ALASKA
}

\author{
by
}

Marwan A. Wartes ${ }^{1}$, Robert J. Gillis ${ }^{1}$, Trystan M. Herriott ${ }^{1}$, Richard G. Stanley ${ }^{2}$, Kenneth P. Helmold ${ }^{3}$, C. Shaun Peterson ${ }^{3}$, and Jeffrey A. Benowitz

\section{INTRODUCTION}

The Alaska Division of Geological \& Geophysical Surveys (DGGS) recently initiated a multi-year review of the hydrocarbon potential of frontier sedimentary basins in Alaska (Swenson and others, 2012). In collaboration with the Alaska Division of Oil \& Gas and the U.S. Geological Survey we conducted reconnaissance field studies in two basins with recognized natural gas potential - the Susitna basin and the Nenana basin (LePain and others, 2012). This paper summarizes our initial work on the Nenana basin; a brief summary of our work in the Susitna basin can be found in Gillis and others (in press).

During early May 2012, we conducted ten days of helicopter-supported fieldwork and reconnaissance sampling along the northern Alaska Range foothills and Yukon-Tanana upland near Fairbanks (fig. 1). The goal of this work was to improve our understanding of the geologic development of the Nenana basin and to collect a suite of samples to better evaluate hydrocarbon potential. Most laboratory analyses have not yet been completed, so this preliminary report serves as a summary of field data and sets the framework for future, more comprehensive analysis to be presented in later publications.

\section{OVERVIEW OF GEOLOGY AND PETROLEUM SYSTEM}

A number of small to moderate sized sedimentary basins lie between the Brooks Range and Alaska Range, including the Nenana, Tanana, and Yukon Flats basins ${ }^{5}(E h m, 1983)$. The subsidence in these basins is clearly tectonic in origin and they appear to be dominantly filled by Cenozoic nonmarine sediment (Kirschner, 1994). The Nenana basin was first recognized as a thick sedimentary basin following the collection of regional gravity data (Barnes, 1961; see contours in fig. 1). Subsequent studies further suggested the basin was likely extensional in origin (Kirschner, 1994), a conclusion later confirmed by seismic data (Van Kooten and others, 2012). The first two exploratory wells (Union Nenana No. 1 and ARCO Totek Hills No. 1) were drilled on the flanks of the Nenana basin (fig. 1) and did not result in commercial discoveries. However, the wells encountered nonmarine sedimentary strata similar in age and lithology to the Eocene to Miocene Usibelli Group exposed in the Healy area along the Alaska Range front (figs. 1 and 2).

The Nenana basin has seen increased exploration activity in recent years, led by Doyon Limited and their partners who acquired new gravity, magnetic, and seismic data. Doyon also drilled the Nunivak 1 well in 2009, reaching a true vertical depth of 11,094 ft. Modeling of their geophysical data and calibration with the well led to their suggestion that the deepest parts of the basin may reach 25,000-30,000 ft (Van Kooten and others, 2012), significantly deeper than previously thought (for example, Hite and Nakayama, 1980; Grether and Morgan, 1988). These interpretations, if correct, suggest that parts of the basin have experienced sufficient burial to mature potential source rocks capable of generating hydrocarbons (Van Kooten and others, 2012).

The possible presence of viable petroleum source rocks in the Nenana basin was discussed in Stanley and others (1990), who reported Rock-Eval pyrolysis and vitrinite reflectance data from outcrop samples taken from the type section of the Usibelli Group at Suntrana, near Healy (figs. 1-3). Although many of the samples were thermally immature with respect to the top of the oil window, the data set suggests that some of the coals, overbank mudstone, and lacustrine mudstone are potential source rocks for oil and gas. The data indicated a wide range of kerogen compositions, most of which were gasprone. However, a number of samples plotted as Type II kerogen, indicating the potential to generate liquid hydrocarbons.

\footnotetext{
${ }^{1}$ Alaska Division of Geological \& Geophysical Surveys, 3354 College Rd., Fairbanks, Alaska 99709-3707; marwan.wartes@alaska.gov

${ }^{2}$ U.S. Geological Survey, 345 Middlefield Road Mail Stop 969, Menlo Park CA 94025-3561

${ }^{3}$ Alaska Division of Oil \& Gas, 550 W. 7th Ave., Suite 800, Anchorage, AK 99501-3560

${ }^{4}$ University of Alaska Fairbanks, Geophysical Institute, P.O. Box 755940, Fairbanks, AK 99775-5940

${ }^{5}$ Previous workers have applied varying naming conventions to the sedimentary basins south and west of Fairbanks (for example, compare Miller and others, 1959; Ehm, 1983; Kirschner, 1988; 1994; Frost and others, 2002; DGGS Staff, 2012). To avoid further confusion, we suggest restricting the term Nenana basin to the well defined gravity low in the Minto Flats area, and applying the term Tanana basin to remaining areas south of the YukonTanana upland (fig. 1). This distinction has the added benefit of drawing attention to the apparent different tectonic origins of the two basins (for example Paleogene extensional subsidence for the Nenana basin [Van Kooten and others, 2012] versus Neogene flexural subsidence of the Tanana foreland basin [Ridgway and others, 2007]).
} 


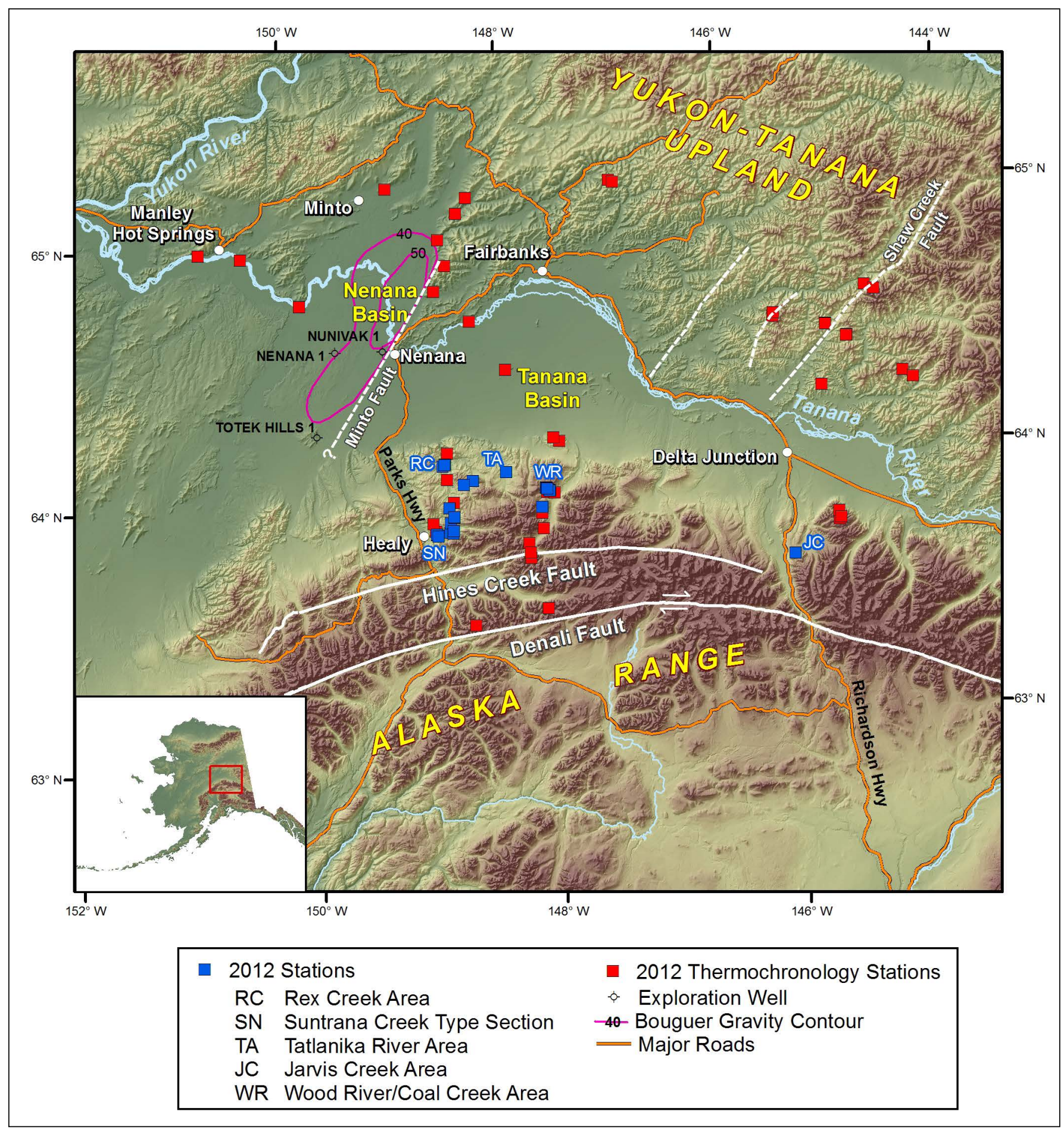

Figure 1. Location map of interior Alaska, highlighting 2012 field stations and salient geologic features noted in the text. The gravity contours are from Troutman and Stanley (2003), as digitized from Kirschner (1988). 


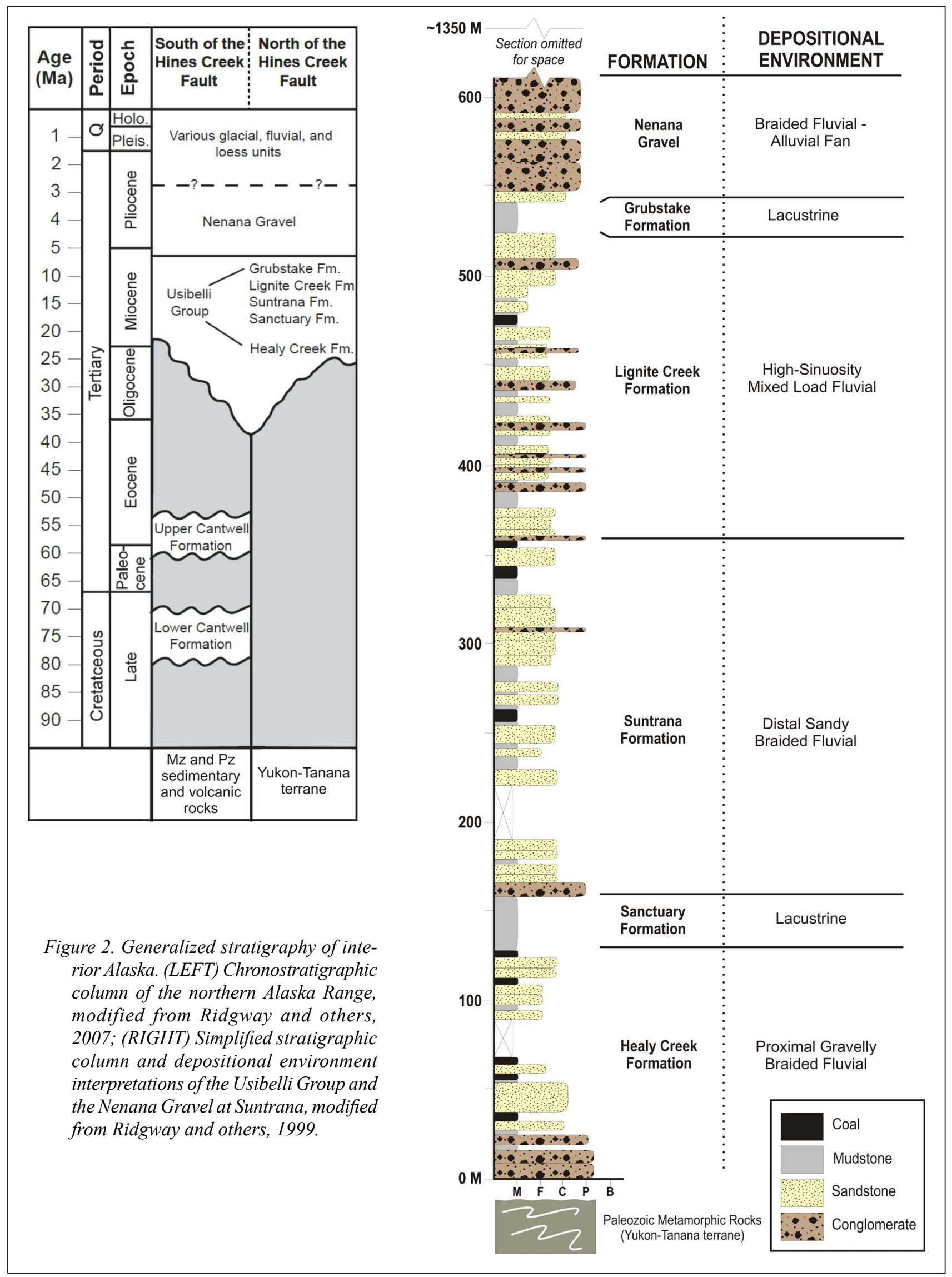




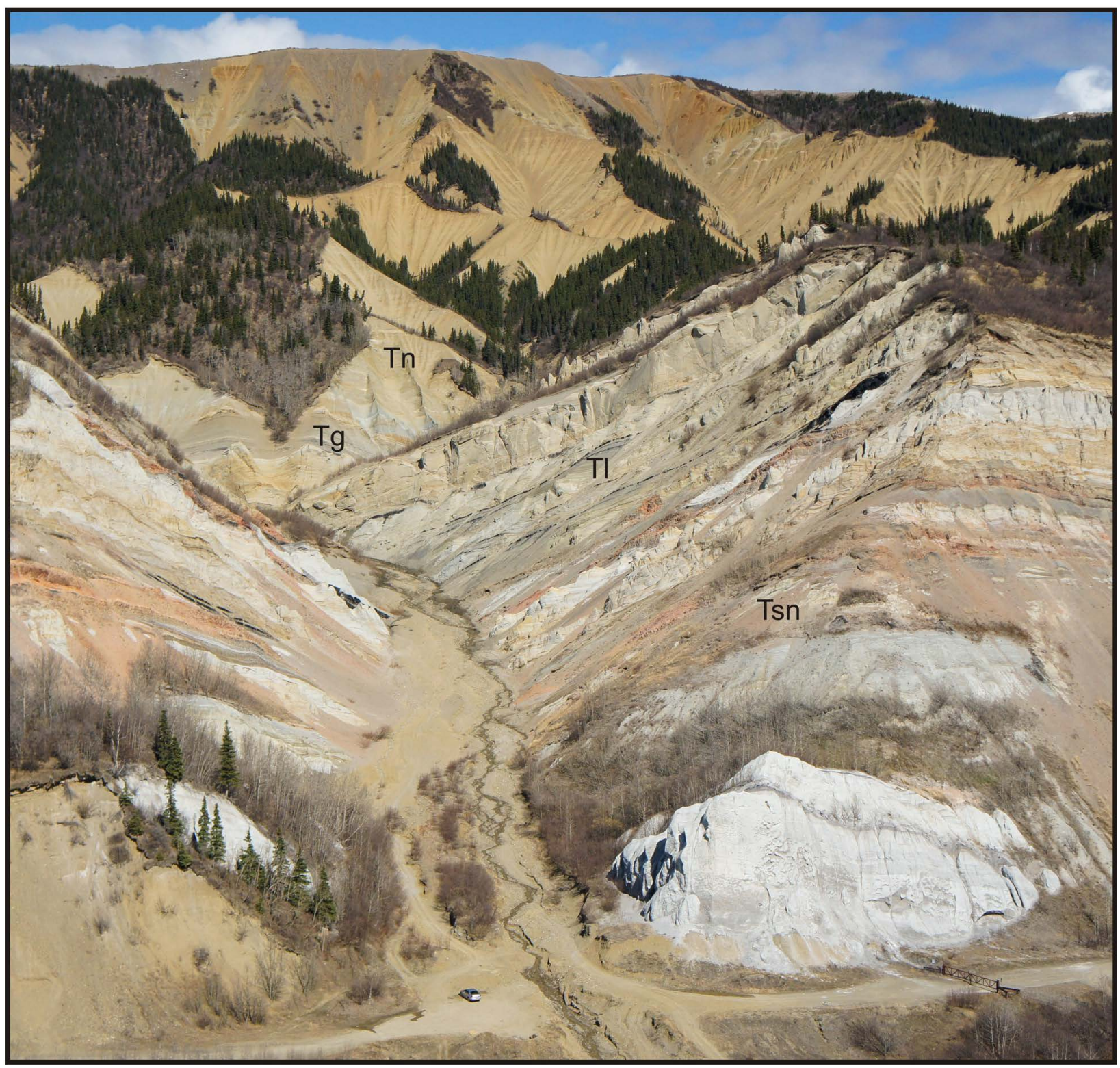

Figure 3. Photograph of the upper part of the type section of the Usibelli Group at Suntrana. The Suntrana Formation (Tsn) forms the light-gray-weathering interval with extensive pale pink-colored clinker (residue from burned coal); the overlying brown-weathering rocks are the Lignite Creek Formation (Tl); the thin Grubstake Formation (Tg) is visible at the confluence of two creeks and underlies the very thick, brown-weathering Nenana Gravel (Tn) forming the uplands in the distance. Note car for scale in lower center of photo.

The occurrence of similar potential source facies in the subsurface Nenana basin was confirmed by analysis of 23 cuttings samples from the Nunivak 1 well, which indicate the presence of kerogens that are intermediate between gas-prone (Type III) and oil-prone (Type II) (Stanley and Lillis, 2011). Additional well samples analyzed by Van Kooten and others (2012) further suggest the presence of viable source rocks.

\section{FIELD STUDIES}

The goal of our brief 2012 reconnaissance fieldwork was to revisit the stratigraphy of the Usibelli Group exposed along the northern Alaska Range and collect a robust suite of samples for modern analyses relating to source rocks (organic geochemistry and thermal maturity) and reservoir quality (porosity and permeability, composition, and provenance). In 
addition, numerous samples were collected for thermochronologic analysis to assess regional patterns of exhumation in interior Alaska. Although the analytical results from field samples are not yet available, a summary of our objectives and activities are included below.

\section{Detailed Reservoir Quality Sampling of Usibelli Group at Suntrana}

The most continuous and accessible section of the Usibelli Group is exposed at the confluence of Suntrana Creek and Healy Creek (SN on fig. 1; see also figs. 2 and 3). Wahrhaftig (1987) assigned this as the type locality for the group, which includes five formations, listed here in ascending order: the Healy Creek, Sanctuary, Suntrana, Lignite Creek, and Grubstake Formations (fig. 2). This section has been studied by a number of previous workers (Wahrhaftig and others, 1969; Buffler and Triplehorn, 1976; Merritt, 1985; Stanley and others, 1992; Ridgway and others, 1999). To assess the reservoir potential of these units, we used the published measured section of Wahrhaftig (1987) to provide accurate stratigraphic context and position for 21 samples collected for compositional and porosity and permeability analyses. Most of the sandstone is weakly indurated to friable and great care was taken to collect large, undisturbed samples that were later encased in epoxy to ensure the physical integrity of samples during transport to the laboratory. This technique has been successfully used elsewhere in Alaska to ensure accurate laboratory results from poorly consolidated Tertiary sediment (Helmold and others, 2011).

\section{Source Rock Sampling of the Lacustrine Sanctuary Formation}

Hydrocarbons in many producing nonmarine basins around the world are sourced from very organic rich, oil-prone lacustrine rocks (Carroll and Bohacs, 2001). The Sanctuary Formation is the most regionally extensive lacustrine unit in the Usibelli Group and we collected laminated mudstone from two localities for Rock-Eval pyrolysis and vitrinite reflectance (fig. 4). These data will help assess source-rock potential and supplement existing results reported in Stanley (1988) and Stanley and others (1990).

\section{Detailed Measured Sections and Facies Analysis Grubstake Formation}

The Grubstake Formation is the youngest unit in the Usibelli Group and is generally regarded as fluvial and lacustrine in origin (Wahrhaftig and others, 1969; fig. 2). To better understand the facies in this unit, we measured a detailed, 17-mthick section along Tatlanika Creek (TA on fig. 1). The lower $\sim 8 \mathrm{~m}$ of section consists of silty claystone overlain abruptly by very-fine-grained sandstone (fig. 5A). The mudstone facies varies from weakly laminated to blocky weathering and locally includes diffuse bioturbation and pedogenic features. The sandstone facies is locally mottled and contains carbonaceous debris. This unit is overlain by a conspicuous $8.2 \mathrm{~m}$ white to yellowish-tan weathering tuff (fig. 5). This ash yielded a weighted mean ${ }^{40} \mathrm{Ar} /{ }^{39} \mathrm{Ar}$ age from mineral separates (plagioclase, hornblende, and biotite) of $6.7 \pm 0.1 \mathrm{Ma}$, suggesting a late Miocene age (Triplehorn and others, 2000). The lower part of the tuff bed includes a 20-cm-thick carbonaceous mudstone that serves as a substrate for large, fossilized tree roots and trunks that are preserved in growth position (fig. 5B). The tuff includes abundant convolute lamination that disrupts original planar and ripple lamination. The tuff is sharply overlain by partially covered brown-weathering silty claystone similar to the lithofacies at the base of the section. A second tuff $(\sim 5 \mathrm{~m}$ thick) is visible approximately $30 \mathrm{~m}$ farther up the bluff, but was inaccessible.

Our observations suggest the base of the exposure records weakly developed shallow lacustrine or overbank facies. The abrupt transition to sandstone may record the encroachment of a deltaic system, possibly a distributary channel. The ash appears to have buried a standing forest, but the sedimentology of the unit suggests it is not a primary ash fall and was probably reworked to some degree by fluvial processes. Our observations and interpretations of this unit are consistent with those reported by Ridgway and others (2007).

\section{Healy Creek Formation}

The Healy Creek Formation is the oldest unit in the Usibelli Group and rests unconformably on a diverse suite of Paleozoic metamorphic rocks of the Yukon-Tanana terrane (fig. 2; Wahrhaftig, 1987; Wilson and others, 1998). At the type section at Suntrana (SN on fig. 1), palynologic data suggest the unit is no older than early Miocene, although data from elsewhere in the region suggest the lower part of the unit is locally as old as late Oligocene (Leopold and Liu, 1994). Wolfe and Tanai (1987) interpreted megafossil floral data from the Healy Creek Formation in the Rex Creek area (RC on fig. 1) and pushed the lower age limit of the unit back even further, assigning a late Eocene age.

The more prospective reservoir units in the subsurface Nenana basin are likely the older, more deeply buried intervals that could be in communication with hydrocarbons migrating from a mature source rock. Therefore, we were interested in investigating the facies of the oldest parts of the Usibelli Group that crop out in the aforementioned Rex Creek area. We measured a 15.5-m-thick section of the Healy Creek Formation along the north side of California Creek, just downstream 
of its confluence with Rex Creek (RC on fig. 1). This is the same area that produced the late Eocene floral ages noted above. The Healy Creek Formation in this area weathers a very light gray to white (fig. 6) due to abundant kaolinite in the unit (Ridgway and others, 2007). The measured section is dominantly interbedded, very light gray to white colored, very-fine- to medium-grained sandstone. Sandstone beds range from tens of centimeters up to $2 \mathrm{~m}$ thick. Grain size and sedimentary structures are difficult to determine, with sugary texture imparted by the clay alteration. Nevertheless, ripple cross-lamination and trough and planar tabular cross-bedding are prevalent. Some sandstone beds fine upward and are

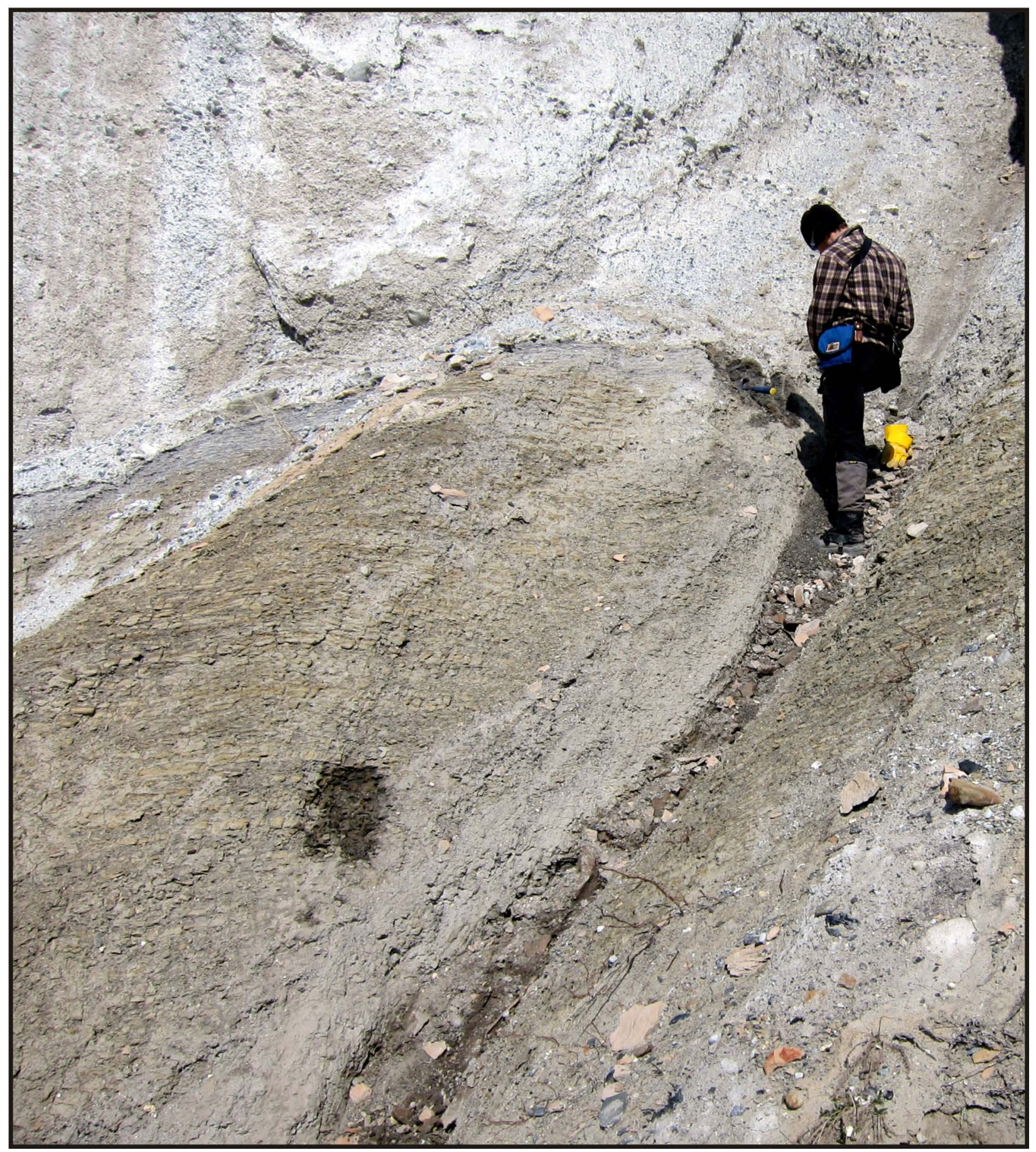

Figure 4. Chocolate-brown-weathering, laminated mudstone, siltstone, and very-fine-grained sandstone of the lacustrine Sanctuary Formation. This facies is typical of those sampled in this study. 
capped by gray, rooted mudstone, carbonaceous mudstone, or thin coals. Approximately ten coalbeds occur in the section, each ranging between 10 and $40 \mathrm{~cm}$ thick. The top of our section includes an abrupt transition into trough cross-bedded granule to pebble conglomerate with lenticular sandstone beds.

The facies observed in the California Creek section are consistent with deposition in a fluvial system with sufficient lateral mobility to periodically disrupt adjacent peat-forming mire environments. This contrasts with younger portions of the Healy Creek Formation, where coalbeds are considerably thicker, albeit laterally discontinuous (Wahrhaftig and others, 1969). The regional variability of this unit (facies, thickness, and age) may reflect episodic extensional subsidence and the formation of sub-basins (see fig. 13 in Ridgway and others, 2007), perhaps similar to the events that initiated the formation of the Nenana basin.

The peculiar abundance of white-weathering clay in this section is enigmatic. Triplehorn (1976) analyzed the clay content of units in the Usibelli Group and noted variations in the montmorillonite and kaolinite content. It remains unclear whether the conspicuous kaolinite we observed in the Healy Creek Formation is primary, reflecting a deeply weathered metamorphic source area, or simply extensive post-depositional alteration of feldspar. Anomalous kaolinite-rich sediments are often interpreted to reflect discrete episodes of elevated weathering during the development of a warm and/or humid climate (for example, Gibson and others, 2000). If the kaolinite-rich character of the Healy Creek Formation proves to be widespread and temporally unique, then analysis of clay mineralogy in the subsurface Nenana basin may provide additional chronologic information to supplement climate-based pollen biostratigraphy.
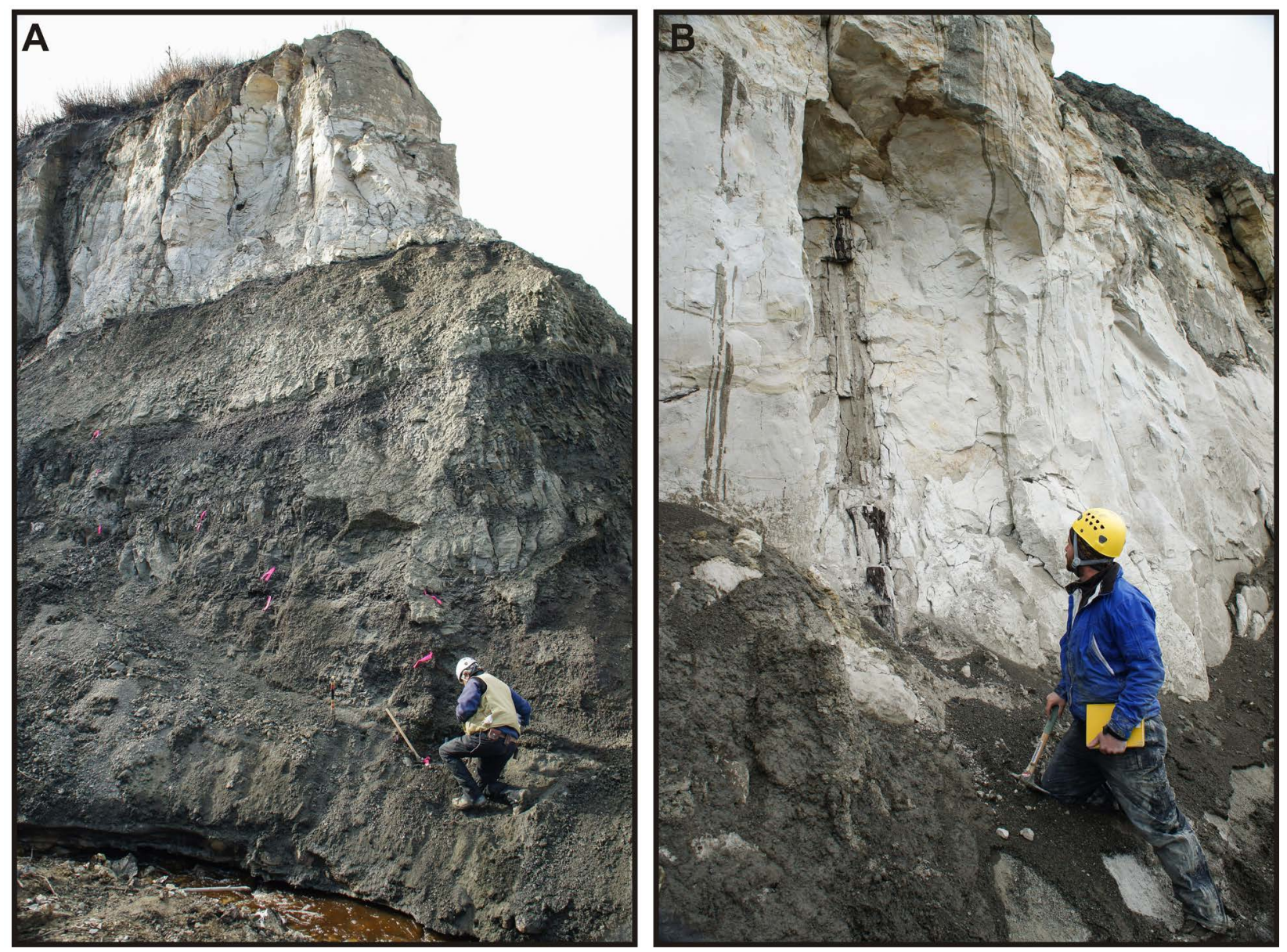

Figure 5. Photos from the measured section of the Grubstake Formation along Tatlanika Creek. (A) Variegated mudstone overlain by brown-weathering sandstone and capped by light-gray-weathering tuff. (B) Close-up view of the reworked tuff with coalified trees in growth position. 

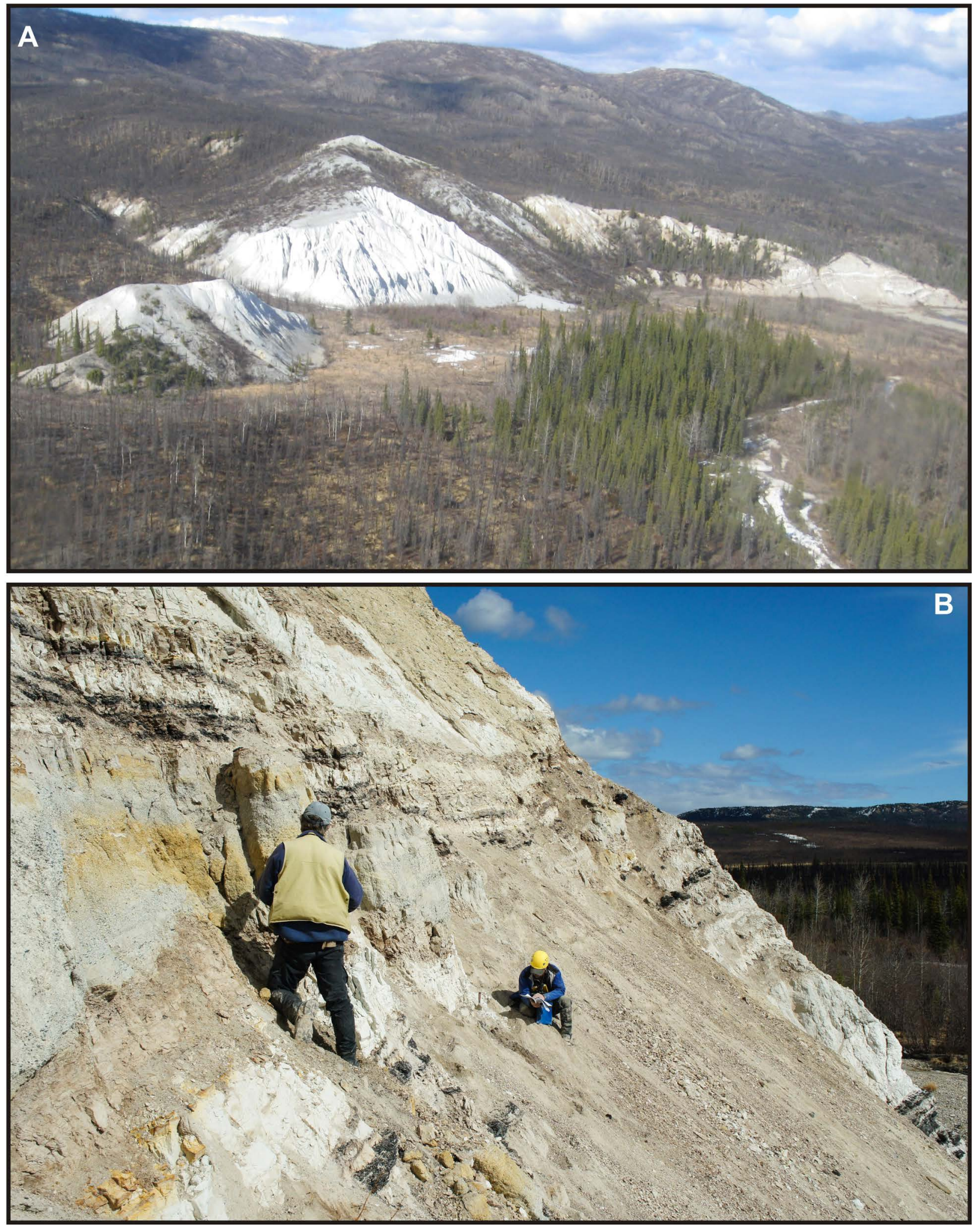

Figure 6. Photos from the measured section of the Healy Creek Formation near the confluence of Rex and California creeks. (A) Aerial view to the northeast of the conspicuous white-weathering outcrops; the color is interpreted to reflect abundant kaolinite in this unit. The detailed section was measured on the bluffs at the far right of the photo. (B) Outcrop view of thin coal beds, carbonaceous mudstone, and kaolinitic sandstone. 


\section{Reconnaissance Facies Analysis and Sampling of the Wood River Area}

To extend our geographic sample coverage and facies observations, we conducted reconnaissance traverses in the upper Coal Creek area, a west tributary of the Wood River (WR in fig. 1). This area contains high-quality exposures of the Suntrana and Lignite Creek Formations with along-strike views that provide for examination of lateral facies changes (fig. 7; see also Merritt [1986]). We collected 11 large sandstone samples for reservoir quality analysis (porosity, permeability, and composition). Detailed facies observations were made at each location to provide depositional environment context for the samples. The section we traversed dominantly comprises very well cross-bedded, fine- to medium-grained sandstone, and lesser granule to pebble conglomerate. Bedform geometries range from trough to planar tabular to planar tangential. Many sedimentation units exhibit clear lenticular geometries reflecting scour and fill processes. Most of the sandstone packages form upward-fining packages up to $25 \mathrm{~m}$ thick and are capped by coals ranging from 1 to $4 \mathrm{~m}$ thick. The observed facies in the Suntrana and lower Lignite Creek Formations suggest deposition occurred in a sandy, braided fluvial system, consistent with prior work on these units along the northern Alaska Range (Buffler and Triplehorn, 1976, Stanley and others, 1992, and Ridgway and others, 2007).

We also conducted a reconnaissance traverse along a gully immediately northwest of upper Coal Creek in an area mapped as the Grubstake Formation (Wahrhaftig and others, 1969). Ridgway and others (2007) calculated that the Grubstake Formation is approximately $550 \mathrm{~m}$ thick here, indicating it is by far the thickest example of this unit in the region. The abundance of sandstone observed at this exposure is more consistent with regional descriptions of the Lignite Creek Formation, raising doubts regarding the mapped formation assignment. However, if the existing interpretations are correct, they imply a marked southward and westward thickening of the late Miocene Grubstake, possibly reflecting spatially variable subsidence association with the nascent exhumation of the Alaska Range.

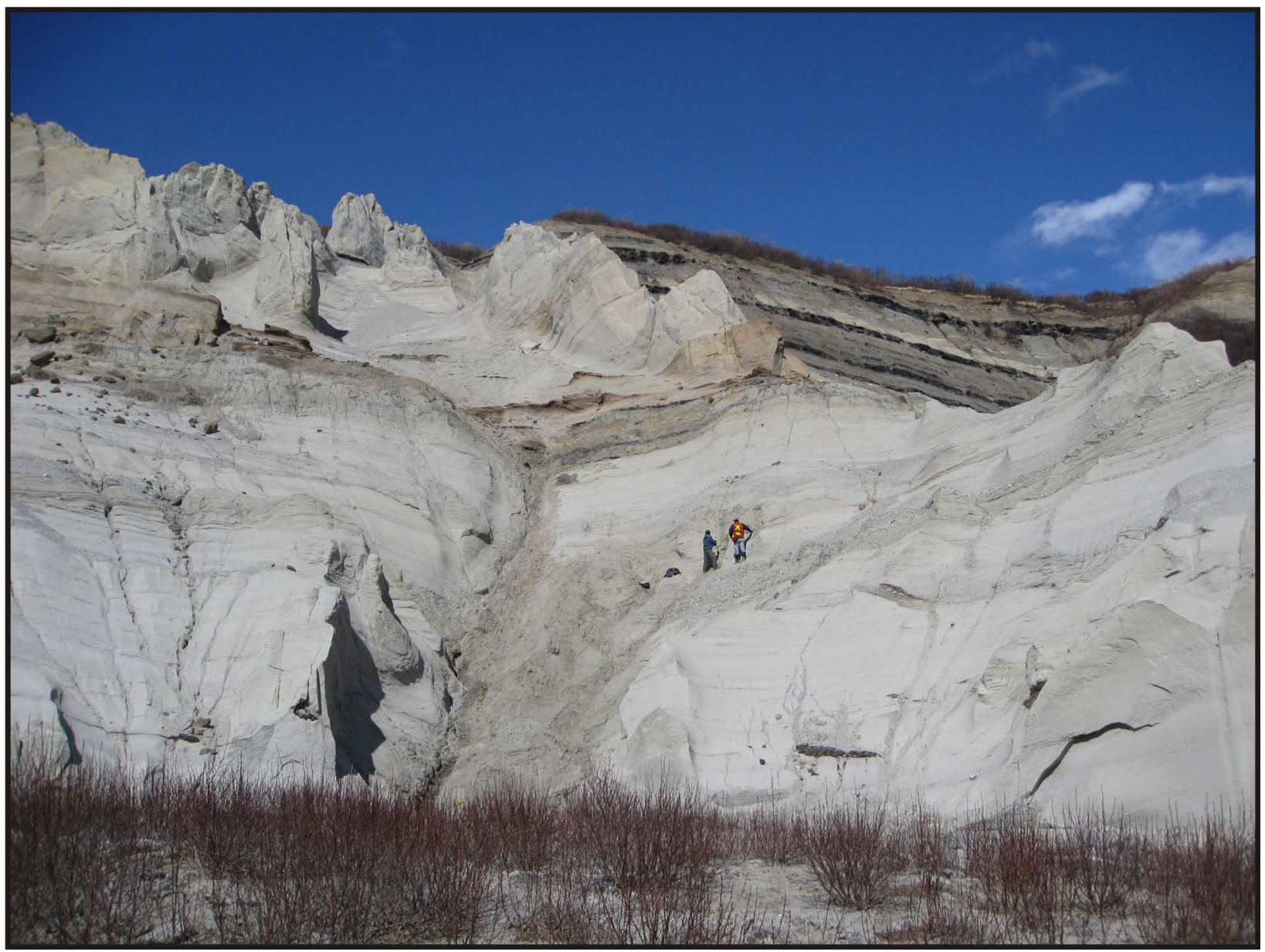

Figure 7. Well exposed section along Coal Creek, a tributary to the Wood River (WR on fig. 1). Light-gray-weathering strata are amalgamated sandstone and conglomerate of the Suntrana Formation. The brown-weathering, coal-bearing exposures along the skyline are from the Lignite Creek Formation. Geologists near photo center indicate scale. 


\section{Reconnaissance Sampling of the Jarvis Creek Area}

To provide a more regional perspective on the Neogene coal-bearing rocks north of the Alaska Range, we conducted a brief reconnaissance of outcrops east of the Richardson Highway, near Jarvis Creek (JC on fig. 1; see also Belowich [1987]). High winds and snow prevented detailed examination of these exposures, although we were able to collect several coal and carbonaceous mudstone samples for further palynologic and source-rock analysis. Ridgway and others (2007) suggested these rocks are most likely correlative with the Lignite Creek Formation.

\section{Thermochronologic Sampling in the Alaska Range and Yukon-Tanana Upland}

The very low relief Minto Flats region suggests the Nenana basin is the site of ongoing tectonic subsidence. The Minto Flats are bounded on the east by the seismically active Minto fault zone (fig. 1; Ruppert and others, 2008), which likely played a significant role in the tectonic development of the Nenana basin (Lesh and Ridgway, 2007). The continued tectonic subsidence and accumulation of Pliocene-Quaternary sediment has buried the older stratigraphy that is relevant to the basins' petroleum system. Due to the lack of exposed Cenozoic strata along the basin margin, we instead investigated the surrounding igneous and metamorphic bedrock of the Yukon-Tanana uplands for evidence of their cooling history. These data will constrain when these regions were uplifted and eroded, providing sediment that subsequently accumulated in the adjacent Nenana basin. The age of exhumation of the Yukon-Tanana upland is not well constrained, although available evidence suggests the Eocene was an important episode of regional cooling and extension (Newberry and others, 1996; Dusel-Bacon and Murphy, 2001; Douglas and others, 2002). The link between Eocene events in the Yukon-Tanana upland and the origin of the Nenana basin remain enigmatic, although it is possible both reflect a major tectonic reorganization of Alaska following the Paleocene-Eocene subduction of an oceanic spreading ridge (Bradley and others, 2003).

We collected about 50 metamorphic and igneous rock samples for thermochronologic analysis (red boxes on fig. 1), principally via the apatite fission track and (U-Th)/He methods. In addition to the areas immediately surrounding the basin, we also collected samples farther east in the Yukon-Tanana uplands and to the south in the Tanana basin and northern foothills of the Alaska Range. Samples collected from the Yukon-Tanana uplands east of Fairbanks targeted both sides of large, northeast-trending faults (fig. 1), some of which coincide with zones of active seismicity (Ruppert and others, 2008). These structures are sub-parallel to the Minto fault that bounds the Nenana basin and may share a common tectonic history.

Samples from the Alaska Range were collected along a transect from south of the Hines Creek fault northward through the foothills fold-thrust belt, continuing across the Tanana basin to the Yukon-Tanana uplands. These new thermochronologic results will provide additional evidence to constrain when the orogen was exhumed and became a major barrier to sediment transport between Interior Alaska and the Susitna basin (see Benowitz and others, 2011), another basin currently being evaluated as part of this program.

\section{SUMMARY AND FUTURE WORK}

We conducted ten days of fieldwork that improved our understanding of the stratigraphy of the Usibelli Group, which serves as a possible outcrop analogue for the subsurface geology of the Nenana basin. We anticipate publishing the detailed interpretations of reservoir quality and source-rock data from our field samples by late 2013. Similarly, upon completion of the laboratory analyses, we expect to have an extensive thermochronologic data set that will be published with accompanying time-temperature modeling and uplift interpretations in the context of available regional tectonic constraints.

Another potential phase of this project in 2013 will be additional evaluation of drill cuttings from the Nunivak well, possibly including supplementary analysis of source-rock character, sandstone provenance, and biostratigraphy. Biostratigraphic interpretations of the Nunivak well presented by Van Kooten and others (2012) suggest that the lower part of the stratigraphy penetrated by the well may be Paleocene (older than any Usibelli Group rocks) and possibly correlative with the Cantwell Formation in the northern Alaska Range (Ridgway and others, 1997). Stanley (1987) reported Rock-Eval pyrolysis data from Cantwell Formation outcrop samples that suggest the unit is dominantly gas prone but may also be capable of generating liquids. In light of these observations and interpretations, we are also considering additional field studies of the Paleocene Cantwell Formation exposed south of the Hines Creek fault in the northern Alaska Range (figs. 1 and 2).

\section{ACKNOWLEDGMENTS}

This work is funded by the State of Alaska in support of frontier basin area exploration that may result in energy for in-state use. This program was initiated by Robert Swenson and David LePain. We are grateful to David Mauel for his efforts to compile existing geologic data relevant to this project, which greatly aided our preparation for fieldwork. We thank Andrea Loveland for GIS and drafting help with figure 1. Diane Shellenbaum, Julie Houle, and Mike Sawlan provided 
useful review comments that improved the text and figures. A special thanks to Quicksilver Air and their capable helicopter pilots for safely ferrying us around in the field.

\section{REFERENCES CITED}

Barnes, D.F., 1961, Gravity low at Minto Flats: U.S. Geological Survey Professional Paper 424-D, p. D254-D257.

Belowich, M.A., 1987, Basinal trends in coal, petrographic, and elemental composition with applications toward seam correlation, Jarvis Creek Coal Field, Alaska, in Rao, P.D., and Walsh, D.E., eds., Focus on Alaska Coal-1986 Proceedings of the Conference: Fairbanks, University of Alaska, Mineral Industry Research Laboratory Report 72, p. 300-335.

Benowitz, J.A., Layer, P.W., Armstrong, P., Perry, S.E., Haeussler, P.J., Fitzgerald, P.G., and Van Laningham, S., 2011, Spatial variations in focused exhumation along a continental-scale strike-slip fault-The Denali fault of the eastern Alaska Range: Geosphere, v. 7, no. 2, p. 455-467.

Bradley, D.C., Kusky, T.M., Haeussler, P.J., Goldfarb, R.J., Miller, M.L., Dumoulin, J.A., Nelson, S.W., and Karl, S.M., 2003, Geologic signature of early Tertiary ridge subduction in Alaska, in Sisson, V.B., Roeske, S.M., and Pavlis, T.L., eds., Geology of a transpressional orogen developed during ridge-trench interaction along the North Pacific margin: Boulder, Colorado, Geological Society of America Special Paper 371, p. 19-49.

Buffler, R.T., and Triplehorn, D.M., 1976, Depositional environments of the Tertiary coal-bearing group, central Alaska, in Miller, T.P., ed., Recent and Ancient Sedimentary Environments in Alaska-Proceedings of the Alaska Geological Society Symposium held April 2-4, 1975, Anchorage: Alaska Geological Society, p. H1-H10.

Carroll, A.R., and Bohacs, K.M., 2001, Lake-type controls on petroleum source-rock potential in nonmarine basins: AAPG Bulletin, v. 85, no. 6, p. 1,033-1,053.

DGGS Staff, 2012, Geologic basins and energy resources of Alaska: Alaska Division of Geological \& Geophysical Surveys Miscellaneous Publication 146, 1 sheet, scale 1:3,700,000.

Douglas, T.A., Layer, P.W., Newberry, R.J., and Keskinen, M.J., 2002, Geochronologic and thermobarometric constraints on the metamorphic history of the Fairbanks mining district, western Yukon-Tanana terrane, Alaska: Canadian Journal of Earth Sciences, v. 39, p. 1,107-1,126.

Dusel-Bacon, Cynthia, and Murphy, J.M., 2001, Apatite fission-track evidence of widespread Eocene heating and exhumation in the Yukon-Tanana Upland, Interior Alaska: Canadian Journal of Earth Sciences, v. 38, no. 8, p. 1,191-1,204.

Ehm, Arlen, 1983, Oil and gas basins map of Alaska: Alaska Division of Geological \& Geophysical Surveys Special Report 32,1 sheet, scale 1:2,500,000.

Frost, G.M., Barnes, D.F., and Stanley, R.G., 2002, Geologic and isostatic gravity map of the Nenana basin area, central Alaska: U.S. Geological Survey Geologic Investigations Series Map I-2534, pamphlet, 16 p., scale 1:250,000.

Gibson, T.G., Bybell, L.M., and Mason, D.B., 2000, Stratigraphic and climatic implications of clay mineral changes around the Paleocene/Eocene boundary of the northeastern U.S. margin: Sedimentary Geology, v. 134, no. 1-2, p. 65-92.

Gillis, R.J., Stanley, R.G., LePain, D.L., Mauel, D.J., Herriott, T.M., Helmold, K.P., Peterson, C.S., Wartes, M.A., and Shellenbaum, D.P., in press, Overview of 2011 reconnaissance field studies in the Susitna basin: Division of Geological \& Geophysical Surveys Preliminary Interpretive Report.

Grether, W.J., and Morgan, K.A., 1988, Exploration and hydrocarbon potential of interior basins, Alaska: American Association of Petroleum Geologists Bulletin, v. 72, no. 2, p. 191-192.

Helmold, K.P., LePain, D.L., Wartes, M.A., Stanley, R.G., Gillis, R.J., Peterson, C.S., and Herriott, T.M., 2011, Reservoir potential of Tertiary and Mesozoic sandstones, Cook Inlet, Alaska [abs.]: Program with Abstracts, 2011 Western Region Meeting, May 6-14, 2011, Anchorage, Alaska, Society of Petroleum Engineers and Pacific Section, American Association of Petroleum Geologists, p. 61-62.

Hite, D.M., and Nakayama, E.N., 1980, Present and potential petroleum basins of Alaska, in Landwehr, M.L., ed., Exploration and economics of the petroleum industry-New ideas, new methods, new developments: Dallas, Texas, Institute on Petroleum Exploration and Economics, p. 511-554.

Kirschner, C.E., 1994, Interior basins of Alaska, in Plafker, George, and Berg, H.C., eds., The Geology of Alaska: Boulder, Colorado, Geological Society of America, The Geology of North America v. G-1, p. 469-493.

1988, Map showing sedimentary basins of onshore and continental shelf areas, Alaska: U.S. Geological Survey Miscellaneous Investigations Series Map 1873, 1 sheet, scale 1:2,500,000.

Leopold, E.B., and Liu, G., 1994, A long pollen sequence of Neogene age, Alaska Range: Quaternary International, v. $22 / 23$, p. $103-140$.

LePain, D.L., Wartes, M.A., Gillis, R.J., Herriott, T.M., and Clough, J.G., 2012, Energy Resources FY12 project descriptions, in DGGS Staff, Alaska Division of Geological \& Geophysical Surveys Annual Report: Alaska Division of Geological \& Geophysical Surveys Annual Report 2011-A, p. 34. 
Lesh, M.E., and Ridgway, K.D., 2007, Geomorphic evidence of active transpressional deformation in the Tanana foreland basin, south-central Alaska, in Ridgway, K.D., and others, eds., Tectonic Growth of a Collisional Continental Margin-Crustal Evolution of Southern Alaska, Geological Society of America Special Paper, v. 431, p. 573-592, doi:10.1130/2007.2431(22).

Merritt, R.D., 1986, Geology and coal resources of the Wood River field, Nenana basin: Alaska Division of Geological \& Geophysical Surveys Public Data File 86-68, 37 p.

1985, Field trip guidebook - Lignite Creek and Healy Creek coalfields, Nenana basin, Alaska: Anchorage, Alaska, American Association of Petroleum Geologists, Pacific Section, 60th Annual Meeting, 58 p.

Miller, D.J., Payne, T.G., and Gryc, George, 1959, Geology of possible petroleum provinces in Alaska: U.S. Geological Survey Bulletin 1094, 131 p., 4 sheets, scale 1:2,500,000.

Newberry, R.J., Bundtzen, T.K., Clautice, K.H., Combellick, R.A., Douglas, Tom, Laird, G.M., Liss, S.A., Pinney, D.S., Reifenstuhl, R.R., and Solie, D.N., 1996, Preliminary geologic map of the Fairbanks mining district, Alaska: Alaska Division of Geological \& Geophysical Surveys Public Data File 96-16, 17 p., 2 sheets, scale 1:63,360.

Ridgway, K.D., Thoms, E.E., Layer, P.W., Lesh, M.E., White, J.M., and Smith, S.V., 2007, Neogene transpressional foreland basin development of the north side of the central Alaska Range, Usibelli Group and Nenana Gravel, Tanana Basin, in Ridgway, K.D., and others, eds., Tectonics Growth of a Collisional Continental Margin - Crustal evolution of southern Alaska: Geological Society of America Special Paper, v. 431, p. 507-547.

Ridgway, K.D., Trop, J.M., and Jones, D.E., 1999, Petrology and provenance of the Neogene Usibelli Group and Nenana Gravel-Implications for the denudation history of the central Alaska Range: Journal of Sedimentary Research, v. 69, no. 6 , p. $1,262-1,275$.

Ridgway, K.D., Trop, J.M., and Sweet, A.R., 1997, Thrust-top basin formation along a suture zone, Cantwell basin, Alaska Range-Implications for development of the Denali fault system: Geological Society of America Bulletin, v. 109, p. 505-523.

Ruppert, N.A., Ridgway, K.D., Freymueller, J.T., Cross, R.S., and Hansen, R.A., 2008, Active tectonics of interior Alaska-A synthesis of seismic, GPS, and geomorphic studies, in Freymueller, J.T., Haeussler, P.J., Wesson, R., and Ekstrom, G., eds., Active tectonics, and seismic potential of Alaska: Washington, D.C., American Geophysical Union, Geophysical Monograph Series 179, p. 109-133.

Stanley, R.G., 1988, Hydrocarbon source potential and thermal maturity of the Sanctuary Formation (middle Miocene), northern foothills of the Alaska Range, in Galloway, J.P., and Hamilton, T.D., eds., Geologic studies in Alaska during 1987: U.S. Geological Survey Circular 1016, p. 117-120.

1987, Thermal maturity and petroleum-source potential of the Cantwell Formation (Paleocene), Alaska Range, in Hamilton, T.D., and Galloway, J.P., eds., Geologic studies in Alaska by the U.S. Geological Survey during 1986: U.S. Geological Survey Circular 998, p. 104-107.

Stanley, R.G., and Lillis, P.G., 2011, Preliminary interpretation of Rock-Eval pyrolysis and vitrinite reflectance results from the Nunivak 1 well in the Nenana basin, central Alaska [abs.]: Program with Abstracts, 2011 Western Region Meeting, May 6-14, 2011: Anchorage, Alaska, Society of Petroleum Engineers and Pacific Section, American Association of Petroleum Geologists, p. 87-88.

Stanley, R.G., Flores, R.M., and Wiley, T.J., 1992, Fluvial facies architecture in the Tertiary Usibelli Group of Suntrana, central Alaska, in Bradley, D.C., and Ford, A.B., eds., Geological Studies in Alaska by the U.S. Geological Survey, 1990: U.S. Geological Survey Bulletin 1999, p. 204-211.

Stanley, R.G., McLean, H., and Pawlewicz, M.J., 1990, Petroleum source potential and thermal maturity of the Tertiary Usibelli Group of Suntrana, Alaska: Geologic Studies in Alaska by the U.S. Geological Survey in 1989: U.S. Geological Survey Bulletin, v. 1946, p. 65-76.

Swenson, R.F., Wartes, M.A., LePain, D.L., and Clough, J.G., 2012, Fossil fuel and geothermal energy sources for local use in Alaska-Summary of available information: Alaska Division of Geological \& Geophysical Surveys Special Report 66, 144 p., 2 sheets, scale 1:3,700,000.

Triplehorn, D.M., 1976, Clay mineralogy and petrology of the coal-bearing group near Healy, Alaska: Alaska Division of Geological and Geophysical Surveys, Geologic Report 52, 14 p.

Triplehorn, D.M., Drake, Jeff, and Layer, P.W., 2000, Preliminary 40Ar/39Ar ages from two units in the Usibelli Group, Healy, Alaska-New light on some old problems, in Pinney, D.S., and Davis, P.K., eds., Short Notes on Alaska Geology 1999: Alaska Division of Geological \& Geophysical Surveys Professional Report 119I, p. 117-127.

Troutman, S.M., and Stanley, R.G., 2003, Maps showing sedimentary basins, surface thermal maturity, and indications of petroleum in the central Alaska province: U.S. Geological Survey Miscellaneous Field Studies Map 2428, http://pubs. usgs.gov/mf/2003/2428/. 
Van Kooten, G.K., Richter, M., and Zippi, P.A., 2012, Alaska’s interior rift basins_A new frontier for discovery: Oil \& Gas Journal, v. 110, no. 1A, p. 48-58.

Wahrhaftig, Clyde, 1987, The Cenozoic section at Suntrana Creek, in Hill, M.L., ed., Geological Society of America, Cordilleran Section, Centennial Field Guide, v. 1., p. 445-450.

Wahrhaftig, Clyde, Wolfe, J.A., Leopold, E.B., and Lanphere, M.A., 1969, The coal-bearing group in the Nenana coal field, Alaska: U.S. Geological Survey, Bulletin 1274-D, 30 p.

Wilson, F.H., Dover, J.H., Bradley, D.C., Weber, F.R., Bundtzen, T.K., and Haeussler, P.J., 1998, Geologic map of central (interior) Alaska: U.S. Geological Survey Open-File Report OF 98-133A, version 1.2, http://pubs.usgs.gov/of/1998/ of98-133-a/.

Wolfe, J.A., and Tanai, T., 1987, Systematics, phylogeny, and distribution of Acer (Maples) in the Cenozoic of western North America: Journal Faculty Science of Hokkaido University, v. 22, p. 1-246. 